CORRECTION

\title{
Correction to: Manager perception and proprietary investment disclosure
}

\section{Caleb Rawson ${ }^{1}$}

Published online: 19 October2021

๑) Springer Science+Business Media, LLC, part of Springer Nature 2021

\section{Correction to: Review of Accounting Studies https://doi.org/10.1007/s11142-021-09629-1}

The original version of this article unfortunately contained some mistakes in Appendix A. Specifically, "Table. 11" was added as a table header and should be deleted so that the appendix matches the references in the text.

The original paper has been corrected.

Publisher's note Springer Nature remains neutral with regard to jurisdictional claims in published maps and institutional affiliations.

The original article can be found online at https://doi.org/10.1007/s11142-021-09629-1

Caleb Rawson crawson@walton.uark.edu

1 Sam M. Walton College of Business, University of Arkansas, Fayetteville, AR, USA 